\title{
ARTICLES
}

\section{A Remedy in Sight: International Clinical Research Regulation in the Wake of Guatemala and Nigeria}

\section{Steven W. Postal and Robyn Whipple Diaz ${ }^{*}$}

The globalization of clinical research is the new reality. In 2009, fifty million people were enrolled in clinical trials worldwide. ${ }^{1}$ Over 31,500 of the approximately 71,400 clinical trials conducted in March 2009 were located beyond the borders of the United States. ${ }^{2}$ The largest pharmaceutical companies are expected to conduct up to $65 \%$ of their FDA-regulated human trials overseas by 2012 , compared with only $44 \%$ in $2009 .{ }^{3}$ The percentage of clinical trials registered by the FDA conducted outside of the United States and Western Europe went from 5\% in 1997 to $29 \%$ in $2007 .{ }^{4}$ Financing is the main driver behind outsourcing of clinical research. While it costs

* JD, Contracts and Grants Specialist, MedStar Health Research Institute, MedStar Health and Robyn Whipple Diaz, Esquire, Associate General Counsel, St. Jude Children's Research Hospital. Opinions expressed ... not those of MedStar Health Research Institute, MedStar Health, or St. Jude Children's Research Hospital.

${ }^{1}$ Praia Shetty, Opinion, Review: Chasing Medical Miracles by Alex O'Meara; With All of Their Ethical Obstacles, Are Clinical Trials Really Worth It?, NEW SCIENTIST, July 11, 2009, at 48, available at http://www.lexisnexis.com/lawschool.

${ }^{2}$ Philip W. Fiscus, Global: Risks for Drug Manufacturers, 56 RisK MGMT., May 2009, at 50, available at http://www.rmmag.com/MGTemplate.cfm?Section=Mag Archive \&NavMenuID=304\&template=/Magazine/DisplayMagazines.cfm $\&$ Archive $=$ 1\&IssueID=335\&AID=3894\&Volume $=56 \&$ ShowArticle $=1$.

${ }^{3} I d$. at 50 .

${ }^{4}$ Kevin B. O'Reilly, Outsourcing Clinical Trials: Is it Ethical to Take Drug Studies Abroad?, Am. MED. News, Sept. 7, 2009, at 15, available at http://www.ama-assn .org/amednews/2009/09/07/prsa0907.htm. 
Volume 6 Issue 1

Winter 2011

approximately $\$ 20,000$ to track a single subject in an American clinical study, it only costs about $\$ 2,000$ per subject in India. ${ }^{5}$

Despite the existence of internationally recognized protections for participants in clinical research, some study sponsors and investigators have failed to provide participants abroad with the rights afforded to research participants in the United States. The sheer number of studies conducted abroad has led to a lack of regulatory oversight, putting some of the world's most vulnerable populations at risk. This article will analyze two particularly egregious studies in which internationally accepted clinical research protections were not available to foreign participants in studies conducted by U.S.-based sponsors. One such study (the "Guatemala Study") took place in the 1940s, but was just recently unearthed from long-forgotten archives. The other study (the "Nigeria Study"), from the 1990s, has been the subject of battles in U.S. courts for the last ten years. While research ethics have evolved significantly since the time of the Guatemala Study, the Nigeria Study and its aftermath demonstrate that more than sixty years after the Guatemala Study, international human subjects remain vulnerable and currently do not have an adequate avenue for redress through the American regulatory and legal system.

This article will discuss these studies, and how they failed to comply with current clinical research regulations. This article will then discuss the shortcomings of new and proposed modifications to clinical research protection, as well as a final rule promulgated by the FDA and application of the "Maryland Model" to federal law. Lastly, the authors argue that the Alien Tort Statute ("ATS") remains the best hope for protecting human subjects by providing a possible remedy for those harmed in clinical trials abroad.

${ }^{5} I d$. at 15 . 


\section{The U.S. Public Health Service Sexually Transmitted DiSEASES INOCULATION STUDY, GUATEMALA, 1946-1948 (THE "GUATEMALA STUDY")}

In October 2010, Secretary of State, Hilary Clinton, and Secretary of Health and Human Services, Katherine Sebelius, issued a joint statement apologizing for an unethical clinical study in Guatemala from 1946-1948, ${ }^{6}$ which was funded by a grant from the National Institutes of Health, then a part of the U.S. Public Health Service ("PHS"). In the Guatemala Study, researchers infected male prisoners, mental patients, and soldiers with syphilis, gonorrhea, and chancroid by introducing them to prostitutes that were either known to be infected or were purposefully infected by the researchers. ${ }^{8}$ In addition, researchers tried to create "inoculations made from syphilis bacteria poured into the men's penises and on forearms and faces that were slightly abraded ... or in a few cases through spinal procedures," and had others drink "syphilitic tissue mixed with water." attempted to infect the women by scraping their mouths, faces, or arms with infected needles. ${ }^{10}$

The researchers sought to determine whether administering penicillin following sexual intercourse could prevent the spread of sexually transmitted diseases. ${ }^{11}$ In total, 427 people were infected with syphilis, 234 were infected

${ }^{6}$ Joint Statement by Secretaries Clinton and Sebelius on a 1946-1948 Study, U.S. DEPARTMENT OF STATE, Oct. 1, 2010, available at http://www.state.gov/secretary/ $\mathrm{rm} / 2010 / 10 / 148464 . h t m$.

${ }^{7}$ Discovery of 1940s Study Ethics Breach Leads to Apology From NIH, Investigation, Medical Research LAw \& POlicy RePORT, Oct. 6, 2010, available at http://news .bna.com/mrln/display/batch_print_display.adp.

${ }^{8}$ Rob Stein, U.S. Apologizes for Newly Revealed Syphilis Experiments Done in Guatemala, WASH. PoST, Oct. 1, 2010, available at http://www.washingtonpost .com/wp-dyn/content/article/2010/10/01/AR2010100104457.html?sid=ST201010010 4522.

${ }^{9} I d$.

${ }^{10} I d$.

${ }^{11} I d$. 
Volume 6 Issue 1

Winter 2011

with gonorrhea, and 128 were infected with chancroid. ${ }^{12}$ While a direct causal link between the experiment and casualties cannot be established, seventyone (71) subjects died while the Study was conducted. ${ }^{13}$ In addition, researchers drew blood from 438 children for further research. ${ }^{14}$

\section{A. Lack of Contemporary Human SubJects Regulation}

In their joint statement, Clinton and Sebelius stated that "The [Guatemala] [S]tudy is a sad reminder that adequate human subject safeguards did not exist a half-century ago." ${ }^{15}$ The Guatemala Study was conducted at a time when clinical research was largely unregulated. ${ }^{16}$ The Guatemala Study took place during the same time period as the Doctors Trial of the Nuremberg Tribunal, a response to medical experiments by Karl Brandt, the senior Nazi medical official during World War II, and more than twenty other Nazi physicians who were charged with conducting medical experiments that amounted to war crimes. ${ }^{17}$ The Doctors Trial was conducted under American rules of procedure, prosecuted by Americans and overseen by American judges. ${ }^{18}$ The Tribunal issued its opinion in August 1947, and

${ }^{12}$ Historian Who Unveiled 1940s STD Studies on Guatemalan Prisoners Recounts Findings, MED. Res. L. \& POL'Y REP., Nov. 3, 2010.

${ }^{13}$ Stein, supra note 8.

${ }^{14}$ Susan M. Reverby, "Normal Exposure" and Inoculation Syphilis: A PHS "Tuskegee" Doctor in Guatemala, 1946-1948, 13-14, J. POL'Y HIST. 6, 18 (2011).

${ }^{15}$ Joint Statement by Secretaries Clinton and Sebelius on a 1946-1948 Study.

${ }^{16}$ Information on Protection of Human Subjects in Research Funded or Regulated by U.S. Government, U.S. DePT. OF HEALTH AND HuMAN Svs., available at http://www .hhs.gov/1946inoculationstudy/protection.html.

17 Harvard Law School Library, Nuremberg Trials Project Digital Document Collection, Introduction to NMT Case 1, U.S.A. vs. Karl Brandt et al., available at http://nuremberg.law.harvard.edu/php/docs_swi.php?DI=1\&text=medical. The crimes charged included medical experiments conducted on concentration camp inmates concerning the effects of and treatments for, among others, malaria, poison gas, sulfanilamide, bone, muscle, and nerve regeneration, bone transplantation, epidemic jaundice, and sterilization. The defendants were also charged with killing concentration camp inmates for anatomical research.

${ }^{18}$ Abdullahi v. Pfizer, Inc., 562 F.3d 163, 177 (2d Cir. 2009).

$\mathrm{P}$ a g e $\mid 4$ 
the Nuremberg Code was finalized in 1949, one year after completion of the Guatemala Study. ${ }^{19}$ The Nuremberg Code, a set of research ethics principles for human experimentation, was the foundation for later-developed U.S. regulations governing conduct in clinical research, particularly with respect to the following concepts: voluntary informed consent, the avoidance of physical and mental harm, the importance of a risk versus benefit analysis, and the protection of the subject against injury, death, and disability. ${ }^{20}$

The Guatemala Study, if conducted today, would have violated several federal regulations governing clinical research. There are currently two sets of regulations. One was issued by the Department of Health and Human Services (HHS), and the other was issued by the Food and Drug Administration (FDA). Despite minor variations between the two, the governing issues are the same. ${ }^{21}$ Because the Guatemala Study was funded by the U.S. Public Health Service (PHS), formerly a division of the Department of Health, Education, and Welfare (HEW), which is now HHS, the Guatemala Study will be referenced against 45 C.F.R $\S 46$, the HHS regulation protecting human subjects. ${ }^{22}$

\section{B. LACK OF INSTITUTIONAL REVIEW BOARD ("IRB") REVIEW}

The Guatemala Study was not reviewed by an Institutional Review Board ("IRB"), which would have minimized the ethical problems with the

\footnotetext{
${ }^{19}$ Final Report to the Secretary of the Army on the Nuremberg War Crimes Trials Under Control Council No. 107 (1949).

${ }^{20}$ The Nuremberg Code, Wartime Experiments on the Inmates of Nazi Concentration Camps, available at http:/www.brown.edu/Courses/Bio_160/Projects2000/Ethics/ THENUREMBURGCODE.html; The Nuremberg Code, NAtl. Inst. OF HeAlth, available at http://ohsr.od.nih.gov/guidelines/nuremberg.html.

${ }^{21}$ For a comparison between the FDA and HHS regulations, see Comparison of FDA and HHS Human Subject Protection Regulations, U.S. FoOD AND DRUG ADMIN., available at http://www.fda.gov/ScienceResearch/SpecialTopics/RunningClinical Trials/EducationalMaterials/ucm112910.htm.

${ }^{22}$ Class Action Complaint for Manuel Guidel Garcia et al. v. Kathleen Sebelius et al., 1, 7, 9 (D. D.C. 2011) (No. 1:11-cv-00557), available at http://articles.law360.s3 .amazonaws.com/0232000/232069/Syphilis\%20complaint.pdf.
}

P a g e $\mid \mathbf{5}$ 
Volume 6 Issue 1

Winter 2011

Study. IRBs were not defined in U.S. law in 1946, and were required only after the Common Rule ${ }^{23}$ was adopted and 45 C.F.R. $\S 46$ was finalized. ${ }^{24}$ Federal regulations codified basic protections ensured by IRB review, including minimal risk, ${ }^{25}$ a positive ratio of risk to benefit, ${ }^{26}$ equitable selection of patients that take into account the challenges posed by conducting research on vulnerable populations, ${ }^{27}$ additional protection to those predisposed to coercion or undue influence, ${ }^{28}$ and informed consent process and documentation. ${ }^{29}$

\section{The Use of Vulnerable Populations}

The Guatemala Study violated current ethical standards of clinical research by using vulnerable populations as subjects. ${ }^{30}$ Specifically, the Study involved multiple vulnerable populations currently protected by U.S. law, including prisoners, wards of the state, and the mentally ill. ${ }^{31}$

Prisoners were originally given "vulnerable population" status in 1978, and are now protected under 45 C.F.R. $\S 46.301$ et seq. ${ }^{32}$ The Guatemala

${ }^{23}$ The Common Rule is also known as the Federal Policy for the Protection of Human Subjects, and is the baseline standard of medical ethics by which any governmentfunded research in the U.S. is held. Various federal agencies have codified it in their respective sections of the C.F.R. See http://www.hhs.gov/ohrp/policy/common.html.

${ }^{24}$ Federal Policy for the Protection of Human Subjects ('Common Rule'), U.S. DEPT. OF HEALTH AND HuMAN Svs., available at http://www.hhs.gov/ohrp/humansubjects/ commonrule/index.html.

${ }^{25} 45$ C.F.R. $\S 46.111(\mathrm{a})(1)(2011)$.

${ }^{26} 45$ C.F.R. $\S 46.111(\mathrm{a})(2)(2011)$.

${ }^{27} 45$ C.F.R. $\S 46.111(\mathrm{a})(3)(2011)$.

${ }^{28} 45$ C.F.R. $\S 46.111$ (b) (2011).

${ }^{29} 45$ C.F.R. $\S 46.111(\mathrm{a})(4)$ and (5) (2011).

${ }^{30}$ Supra note 12.

${ }^{31}$ See 45 C.F.R. $\S 46.301$ et seq., 45 C.F.R. $\S 46.409$, and the Belmont Report of the National Commission, described below.

${ }^{32} 43$ Fed. Reg. 53,652 (Nov. 16, 1978).

P a g e $\mid 6$ 
Study, conducted in the 1940s, did not protect prisoners in the manner that is required of research conducted today. The subjects' incarceration and lack of access to the outside world likely left them more inclined than a free person to receive the research inoculations or to sleep with prostitutes. The risks involved in the research, therefore, were not commensurate with risks that would be accepted by non-prisoner volunteers. ${ }^{33}$ Since IRBs did not exist at the time, there was also no IRB review of the treatment of prisoners. ${ }^{34}$ Furthermore, the prisoner component of the Study did not constitute permitted research, as it did not focus on prisons as institutional structures ${ }^{35}$ or on prisoners as incarcerated persons ${ }^{36}$ or as a class. ${ }^{37}$

The next set of vulnerable subjects in the Guatemala Study were wards of the state, originally given federal protection in 1983 and now protected by 45 C.F.R. $\S 46.409 .^{38}$ This research, too, would now be impermissible, even though it only involved drawing blood. ${ }^{39}$ The research was not related to the status of the children as wards, ${ }^{40}$ it was not conducted in a setting in which the majority of children involved as subjects were not wards ${ }^{41}$ (i.e. it was conducted in an orphanage), and there was no advocate appointed for the children. $^{42}$

The last category of vulnerable persons in the Study was the mentally ill. While there is no particular section in federal regulations protecting mentally ill research subjects, in 1979, the Belmont Report of the National

\footnotetext{
${ }^{33} 45$ C.F.R. $\S 46.305(\mathrm{a})(3)$ (2011).

${ }^{34} 45$ C.F.R. $\S 46.305$ (a) (2011).

${ }^{35} 45$ C.F.R. $\S 46.306(a)(2)(i i)$ (2011).

${ }^{36} I d$.

${ }^{37} 45$ C.F.R. $\S 46.306(a)(2)($ iii) (2011).

${ }^{38} 48$ Fed. Reg. 9,814 (Mar. 8, 1983).

${ }^{39} 45$ C.F.R. $\S 46.409$ (2011).

${ }^{40} 45$ C.F.R. $\S 46.409$ (a)(1) (2011).

${ }^{41} 45$ C.F.R. $\S 46.409$ (a)(2) (2011).

${ }^{42} 45$ C.F.R. $\S 46.409$ (b) (2011).
} 
Volume 6 Issue 1

Winter 2011

Commission $^{43}$ identified the need for special protections for persons with mental illness when they participate as research subjects. Specifically, it stated:

Special provision may need to be made when comprehension is severely limited-for example, by conditions of immaturity or mental disability. Each class of subjects that one might consider as incompetent (e.g., infants and young children, mentally disabled patients the terminally ill and the comatose) should be considered on its own terms. [...] Respect for persons also requires seeking the permission of other parties in order to protect the subjects from harm. Such persons are thus respected both by acknowledging their own wishes and by the use of third parties to protect them from harm. ${ }^{44}$

\section{LACK OF INFORMED CONSENT}

Despite informed consent being "widely regarded as an ethical norm long before the 1940s," ${ }^{45}$ the Guatemala Study researchers infected subjects with STDs without their knowledge or without obtaining informed consent. ${ }^{46}$ Specifically, the researchers did not inform the adult subjects that the

\footnotetext{
${ }^{43}$ See National Institutes of Health: The Belmont Report, available at http://ohsr .od.nih.gov/guidelines/belmont.html. "On July 12, 1974, the National Research Act (Pub. L. 93-348) was signed into law, thereby creating the National Commission for the Protection of Human Subjects for Biomedical and Behavioral Research. One of the charges to the Commission was to identify the basic ethical principles that should underlie the conduct of biomedical and behavioral research involving human subjects and to develop guidelines which should be followed to assure that such research is conducted in accordance with those principles... . The Belmont Report attempts to summarize the basic ethical principles identified by the Commission in the course of its deliberations."

${ }^{44}$ Kenneth John Ryan, M.D. et al., The Belmont Report: Ethical Principles and Guidelines for the Protection of Human Subjects of Research, THE NATL. COMM. FOR the Protection of Human Subj. of Biomed. \& Behav. Research, Apr. 18, 1979, available at http://ohsr.od.nih.gov/guidelines/belmont.html.

${ }^{45}$ Garcia v. Sebelius, 475 F.2d at 14.

${ }^{46}$ Discovery of 1940s Study Ethics Breach Leads to Apology From NIH, supra note 7.
} 
inoculations were made with the syphilis bacteria. ${ }^{47}$ In some cases, instead of obtaining informed consent, researchers provided cigarettes to subjects in order to obtain compliance. ${ }^{48}$ In the Study, one PHS doctor corresponded to another, "I am a bit, in fact more than a bit, leery of the experiment with the insane people. They cannot give consent, do not know what is going on, and if some goody organization got wind of the work, they would raise a lot of smoke." ${ }^{49}$ The PHS officials were concerned "about the morality of doing this in the mental hospital and about consent." ${ }^{50}$ As previously noted, researchers also took blood samples from 483 children in the national orphanage without obtaining consent. ${ }^{51}$

Rather than obtaining the informed consent of subjects, researchers sought cooperation from Guatemalan government officials and the institutions housing the subjects (i.e. mental institutions, prisons, or orphanages). ${ }^{52}$ Researchers provided medications, medical treatment and refrigeration in exchange for such cooperation. ${ }^{53}$ Also, researchers deceived Guatemalan officials during the experiments. ${ }^{54}$ For example, the mental asylum officials were led to believe that the inoculums were drugs and not active sexually transmitted diseases. ${ }^{55}$ In general, "correspondence between PHS officials demonstrates that they knew that they were hiding something and that these studies could not be done in the United States."

\footnotetext{
${ }^{47}$ Supra note 12.

${ }^{48}$ Garcia v. Sebelius, 475 F.2d at 6.

${ }^{49}$ Reverby, supra note 14, at 23.

${ }^{50}$ Supra note 12.

${ }^{51}$ Reverby, supra note 14, at 13-14.

${ }^{52}$ Garcia v. Sebelius, 475 F.2d at 4-5.

${ }^{53} I d$. at $5,22$.

${ }^{54}$ Supra note 12.

${ }^{55} \mathrm{Id}$.

${ }^{56} I d$.
} 


\section{E. The ObAMA Administration's Response to GUATEMALA, AND REgULATORY REPERCUSSIONS}

In November 2010, a month after Clinton and Sebelius's joint statement, President Obama charged the Presidential Commission for the Study of Bioethical Issues ("PCSBI") with further investigating the facts of the Guatemala Study and convening a panel that would conduct "a thorough review of human subjects protection to determine if Federal regulations and international standards adequately guard the health and well-being of participants in scientific studies supported by the Federal Government. ${ }^{157}$ The President asked PCSBI to begin its work in January 2011, and to report back to him with a completed report of its findings in September $2011 .{ }^{58}$ On March 1, 2011, the PCSBI named the fourteen members of the International Research Panel, most of whom were not from the United States. ${ }^{59}$ The PCSBI met in New York on May 18 and 19, 2011. PCSBI Executive Director Valerie Bonham briefed PCSBI on the status of the fact-finding investigation, and Guatemala's Vice President, Rafael Espada, M.D., briefed PCSBI on what Guatemala's independent investigation had revealed. ${ }^{60}$ Espada stated that "archivists in Guatemala used Guatemalan records to independently confirm [Reverby's research], to establish the depth of the events and to confirm the intentional infection of vulnerable populations such as inmates,

${ }^{57}$ Barack Obama, Memorandum for Dr. Amy Gutmann: Review of Human Subjects Protection, The White House Office of the Press Secretary, Nov. 24, 2010, available at http://www.whitehouse.gov/the-press-office/2010/11/24/presidentialmemorandum-review-human-subjects-protection.

${ }^{58} \mathrm{Id}$.

${ }^{59}$ Bioethics Panel Names Group to Study Worldwide Standards for Research Subjects, Medical ReSEARCh LAW \& POLICY RePORT, Mar. 16, 2011, available at http://news.bna.com/mrln/display/batch_print_display.adp.

${ }^{60}$ President's Bioethics Commission Meets to Continue Consideration of Human Subjects Protection at President's Request, The Presidential COMMISSION FOR THE STUDY OF BIOETHICAL ISSUES, available at http://bioethics.gov/cms/node/211.

P a g e | 10 
soldiers, prostitutes and patients at a mental hospital." ${ }^{61}$ The archivists found no evidence of consent by the subjects. ${ }^{62}$

On September 13, 2011, PCSBI released a report containing its findings, and PCSBI Chair Amy Gutmann stated that the Guatemala Study "involved unconscionable basic violations of ethics, even as judged against the researchers' own recognition of the requirements of the medical ethics of the day." ${ }^{63}$ PCSBI concluded that the researchers in the Guatemala Study intentionally exposed approximately 1,300 people to STDs, and did not obtain the consent of the subjects before engaging in research. ${ }^{64}$ PCSBI made particular note of the fact that many of the researchers involved in the Guatemala Study were also involved in an earlier study involving prisoners in Terre Haute, Indiana, and in that U.S.-based study, the researchers obtained consent from the subjects. ${ }^{65}$ Gutmann stated, "[w]e know the researchers ... disregarded this fundamental ethical standard in Guatemala. The double standard is shocking." 66

It remains too early to tell what substantive regulatory changes, if any, will be made in the wake of the Guatemala findings. On March 2, 2011, the Commission requested public comment on current federal and international human subjects research standards. ${ }^{67}$ Included in the list of requested comments are those pertaining to "existing standards for protecting human subjects ... internationally[,] ... the ethical and social justice issues that

${ }^{61} I d$.

${ }^{62} \mathrm{Id}$.

${ }^{63}$ PCSBI Press Release, President's Bioethics Commission Releases Result of its Historical Investigation of the 1940s U.S. Public Health Service STD Studies in Guatemala, Sept. 13, 2011, available at http://www.bioethics.gov/cms/node/308.

${ }^{64} I d$.

${ }^{65} \mathrm{Id}$.

${ }^{66} I d$.; see also PCSBI, Ethically Impossible: STD Research in Guatemala from 1946 to 1948 , available at $\mathrm{http} / / \mathrm{www} \cdot$ bioethics.gov/cms/sites/default/filesEthicallyImpossible_PCSBI.pdf.

${ }^{67} 76$ Fed. Reg. 11,482 (Mar. 2, 2011).

P a g e | 11 
Volume 6 Issue 1

Winter 2011

emerge from the current research system[,] ... trial design[, and] duties to participants. ${ }^{68}$

\section{The Pfizer Trovan Study, Nigeria, 1996 (The "Nigeria STUDY")}

In 1996, northern Nigeria faced an epidemic of bacterial meningitis. ${ }^{69}$ Pfizer, seeking to gain FDA approval for the use of its new antibiotic Trovafloxacin Mesylate ("Trovan") on children, sponsored a joint American and Nigerian physician team to administer Trovan to residents of Kano, Nigeria in April $1996 .^{70}$ The Study took place at the Infectious Disease Hospital ("IDH") and approximately two hundred children were recruited to serve as test subjects for the new drug. ${ }^{71}$

At the conclusion of the experiment, eleven (11) children had died, while others suffered a range of symptoms relating to meningitis, including blindness, lameness, deafness, seizures and disorientation. ${ }^{72}$ One subject was unable to walk or talk. ${ }^{73}$ While courts and other sources have yet to find a definitive causal link between Trovan and the deaths, at least some of the children died mere hours or days after taking Trovan. ${ }^{74} \mathrm{~A}$ ten-year-old girl continued to receive Trovan for three days as her condition worsened, only to die while still on Trovan. ${ }^{75}$ Pfizer has insisted "that none of the patients died

${ }^{68} 76$ Fed. Reg. 11,483 (Mar. 2, 2011).

${ }^{69}$ Abdullahi v. Pfizer, Inc., 562 F.3d 163, 169 (2d Cir. 2009).

${ }^{70}$ Id. at 169 .

${ }^{71} I d$.

72 Joe Stephens, Where Profits and Lives Hang in Balance, WASH. Post, Dec. 17, 2000, at A01, available at http:/www.washingtonpost.com/wp-dyn/content/article/ 2007/07/02/AR2007070201255.html.

${ }^{73} I d$.

${ }^{74} I d$.

${ }^{75}$ Joe Stephens, Panel Faults Pfizer in '96 Clinical Trial in Nigeria, WASH. Post, May 7, 2006, at A01, available at http://www.washingtonpost.com/wp-dyn/content/ article/2006/05/06/AR2006050601338.html.

P a g e | 12 
as a result of the application of Trovan ... any deaths were the direct result of the meningitis illness and not the treatment provided during the clinical study." ${ }^{76}$ Nonetheless, an independent Nigerian report later found that Pfizer had seriously deviated from its protocol, compromising the care of the subjects. $^{77}$

\section{A. Flaws in Research Design AND ExeCUTION}

As the Nigeria Study involved pharmaceutical research, this section will discuss the FDA regulations governing human subjects research. The two sections in the Federal Register pertaining to FDA's jurisdiction in human subjects are 21 C.F.R. $\S 56$ (Institutional Review Boards) and 21 C.F.R. $\S 50$ (Protection of Human Subjects). Section 50.1 states that protection of human subjects applies to "all clinical investigations regulated by the Food and Drug Administration ... including ... drugs for human use ... Compliance with these parts is intended to protect the rights and safety of subjects involved in investigations filed with the Food and Drug Administration." ${ }^{78}$ The FDA had jurisdiction over the Trovan clinical trial under section 21 C.F.R. $\S 50.1$ as Trovan is a drug and the experiment was a clinical investigation filed with the Food and Drug Administration. ${ }^{79}$

The Nigeria Study involved children as subjects, and therefore implicated 21 C.F.R. $\S 50$ Subpart D. Specifically, the Trovan experiment was governed by 21 C.F.R. $\S 50.52$, as it involved "greater than minimal risk but present[ed] the prospect of direct benefit to individual subjects." ${ }^{80}$ The applicable regulation states that such research may involve children as subjects only if the IRB finds and documents that:

\footnotetext{
${ }^{76}$ Statement of Defense, Attorney General of Kano State v. Pfizer International Incorporated et al., High Court of Kano State, Suit No. K/233/2007, available at http://www.pfizer.com/files/news/trovan_litigation_statement_defense.pdf.

${ }^{77}$ Stephens, supra note 75.

${ }^{78} 21$ C.F.R $\S 50.1$ (a) (2011).

${ }^{79}$ Trovan Fact Sheet, PFIZER.COM, 1, available at http://www.pfizer.com/files/news/ trovan_fact_sheet_final.pdf.

${ }^{80} 21$ C.F.R $\S 50.52$.
} 


\section{Volume 6 Issue 1}

Winter 2011

(a) the risk is justified by the anticipated benefit to the subjects; (b) the relation of the anticipated benefit to the risk is at least as favorable to the subjects as that presented by available alternative approaches; and (c) adequate provisions are made for soliciting the assent of the children and permission of their parents or guardians. ${ }^{81}$

These statutory requirements failed to provide adequate protection for the child subjects in several respects. First, an IRB or ethics committee never actually approved the trial. ${ }^{82}$ Pfizer did not have the Study reviewed in advance by an ethics committee, which is required of a sponsor of a foreign clinical study seeking FDA approval. ${ }^{83}$ One Nigerian doctor stated that "there was no ethical committee at the time of the trial, none met, and no approval was properly given for the trial. ${ }^{184}$ In fact, the principal investigator confessed to forging a letter following the experiment's completion, stating that the trial had been pre-approved by the IDH's ethics committee, and then backdating the letter to a week before the experiment commenced. ${ }^{85}$ Pfizer allegedly paid him $\$ 20,000$ to do this. ${ }^{86}$ Pfizer then reportedly used the letter to justify the Study when speaking with the media, and also gave the letter to the FDA. ${ }^{87}$

${ }^{81} I d$.

${ }^{82}$ Fazal Khan, The Human Factor: Globalizing Ethical Standards in Drug Trials Through Market Exclusion, 57 DePAUL L. REV. 877, 899 (2008).

${ }^{83}$ Stephens, supra note 75.

${ }^{84}$ Sonia Shah, Globalizing Clinical Research, ThE NATION, July 1, 2002, at 26, available at http://www.thenation.com/doc/20020701/shah.

${ }^{85}$ Stephens, supra note 75. See also Amy F. Wollensack, Closing the Constant Garden: The Regulation and Responsibility of U.S. Pharmaceutical Companies Doing Research on Human Subjects in Developing Nations, 6 WASH. U. GLOBAL STUD. L. REV. 747, 756 (2007).

${ }^{86}$ Joe Stephens, Pfizer Faces New Charges Over Nigerian Drug Test, WASH. Post, June 2, 2007, at D01, available at http://www.washingtonpost.com/wp-dyn/content/ article/2007/06/01/AR2007060102197.html.

${ }^{87}$ Stephens, supra note 75.

P a g e | 14 
Pfizer denies these allegations, insisting that the company believed that proper procedures had been followed at the time. ${ }^{88}$

Furthermore, the Study arguably violated 21 C.F.R. $§ 50.52(a)$, as the high risk of the Study did not justify the anticipated benefit to the subjects. Little was known about Trovan before the Study, as available data was insufficient and clinically discouraging. For example, the Nigeria Study marked the first time Trovan was being tested in children in its oral form. ${ }^{89}$ Trovan had also caused significant side effects in animal testing, including liver damage, a degenerative bone condition, and other damage to joints and cartilage. ${ }^{90}$

Researchers allegedly exposed the subjects to additional unnecessary and preventable risks. A Pfizer employee hastily prepared the protocol, completing it in just six weeks, as compared to a more typical time frame in the United States of about one year. ${ }^{91}$ Researchers allegedly did not conduct preliminary tests to determine: 1) if the children in the Study actually had meningitis; and 2) if the strain of meningitis affecting northern Nigeria was responsive to Trovan. ${ }^{92}$ They also allegedly did not screen out children who had joint and liver problems and did not switch them to the control group, as

${ }^{88} \mathrm{Id}$.

${ }^{89}$ Abdullahi v. Pfizer, Inc., 562 F.3d 163, 169 (2d Cir. 2009). However, Pfizer contends that dosing studies "had been conducted in both adults and children and showed that the drug behaved similarly in adults as it did in children before the Kano trial was conducted." Statement of Defense, Attorney General of Kano State v. Pfizer International Incorporated et al., High Court of Kano State, Suit No. K/233/2007, available at http://www.pfizer.com/files/news/trovan_litigation_statement_defense .pdf.

${ }^{90} I d$. at 169.

${ }^{91}$ Stephens, supra note 72.

${ }^{92} 21$ C.F.R. § 50.52(b) (2001); Abdullahi, 562 F.3d at 170. Pfizer contends that each patient was physically examined for symptoms of meningitis, and that a diagnostic lumbar puncture was performed. See Statement of Defense, Attorney General of Kano State v. Pfizer International Incorporated et al., High Court of Kano State, Suit No. $\mathrm{K} / 233 / 2007$, available at http://www.pfizer.com/files/news/trovan_litigation_ statement_defense.pdf. 


\section{Volume 6 Issue 1}

Winter 2011

promised, if they were not responding well to Trovan. ${ }^{93}$ Administrators reportedly failed to conduct blood tests and spinal taps called for in the Study protocol to assess the safety and efficacy of Trovan. ${ }^{94}$ Following the twoweek experiment, Pfizer researchers and clinicians are alleged to have left the hospital without providing follow-up care. ${ }^{95}$

The trial also allegedly violated 21 C.F.R. $\S 50.52(\mathrm{~b})$ as the researchers allegedly did not present available alternative approaches to the subjects properly. ${ }^{96}$ Specifically, claims have been made that patients in the control group were given only one-third of the recommended dose of the antibiotic ceftriaxone. ${ }^{97}$ This would have rendered the otherwise FDA-approved safe and effective antibiotic therapeutically ineffective, reportedly in an effort to exaggerate the comparative effectiveness of Trovan. ${ }^{98}$ Pfizer, however, denies intentionally using a lower dosage of ceftriaxone. ${ }^{99}$

\section{B. LACK OF INFORMED CONSENT}

As described below, Pfizer investigators allegedly failed to obtain sufficient "assent of the children and permission of their parents or guardians" in accordance with 21 C.F.R. $\S 50.52(\mathrm{c}){ }^{100}$ Section 50.20 discusses the

\footnotetext{
${ }^{93} I d$. at 170 .

${ }^{94}$ Stephens, supra note 72.

${ }^{95}$ See Abdullahi, 562 F.3d at 169. However, Pfizer has stated that "four weeks after concluding the study - on May 15, 1996 - a follow-up exam of study participants was conducted ... [and] no unusual side-effects to meningitis were noted." Statement of Defense, Attorney General of Kano State v. Pfizer International Incorporated et al., High Court of Kano State, Suit No. K/233/2007, available at http://www.pfizer.com/ files/news/trovan_litigation_statement_defense.pdf.

${ }^{96}$ Stephens, supra note 72.

${ }^{97}$ Id.

${ }^{98}$ Khan, supra note 82 , at 900.

${ }^{99}$ Statement of Defense, Attorney General of Kano State v. Pfizer International Incorporated et al., High Court of Kano State, Suit No. K/233/2007, available at http://www.pfizer.com/files/news/trovan_litigation_statement_defense.pdf.
}

${ }^{100} 21$ C.F.R. $\S 50.52$ (c) (2011). See also Abdullahi, 562 F.3d at 169. 
necessary elements of informed consent. ${ }^{101}$ The regulation states that the investigator shall provide: "[a] statement that the study involves research ... and identification of any procedures which are experimental," ${ }^{102}$ "[a] description of any reasonably foreseeable risks or discomforts to the subject"103 and "[a] disclosure of appropriate alternative procedures or courses of treatment, if any, that might be advantageous to the subject." ${ }^{104}$ The Nigeria Study allegedly did not comply with these regulations. The subjects and their guardians purportedly did not know that they were participating in a research experiment. ${ }^{105}$ Pfizer allegedly did not inform the children or their guardians of the risks involved or viable alternative treatments, such as a free, conventional, and effective treatment provided in the same hospital by Doctors Without Borders. ${ }^{106}$

The regulations additionally provide, "information that is given to the subject or the representative shall be in a language understandable to the

${ }^{101}$ For purposes of this article, the authors assume that the children are not of the age of consent, and are rather assenting to treatment, while the parent/guardian is consenting. The United States Court of Appeals stated, "Plaintiffs are minors and their guardians ... [authors' emphasis]." See Abdullahi v. Pfizer, Inc., 77 F. App'x 48 (2d Cir. Oct. 8, 2003). The FDA regulations define children as "persons who have not attained the legal age for consent to treatments or procedures involved in clinical investigations, under the applicable law of the jurisdiction in which the clinical investigation will be conducted." See 21 C.F.R. $\S 50.3(0)$ (2011).

${ }^{102} 21$ C.F.R. $\S 50.25(\mathrm{a})(1)(2011)$.

${ }^{103} 21$ C.F.R. $\S 50.25(\mathrm{a})(2)$.

${ }^{104} 21$ C.F.R. $\S 50.25(\mathrm{a})(4)$.

${ }^{105}$ Stephens, supra note 72.

${ }^{106}$ Abdullahi v. Pfizer, Inc., 562 F.3d 163, 170 (2d Cir. 2009). Pfizer has stated, however, that the treatment provided by Doctors Without Borders was "an injectable drug that was not approved for use in Nigeria and the United States and caused significant pain to patients." Pfizer also contends that Nigerian nurses at IDF informed the children's parents or guardians that they could choose between the treatment provided by Doctors Without Borders and Trovan. Statement of Defence, Attorney General of Kano State v. Pfizer International Incorporated et al., High Court of Kano State, Suit No. K/233/2007, available at http://www.pfizer.com/files/news/ trovan_litigation_statement_defense.pdf.

P a g e | 17 
Volume 6 Issue 1

Winter 2011

subject or the representative." ${ }^{107}$ This allegedly was not the case during the Nigeria Study. Pfizer employees asserted that the nurses explained the specifics of the Nigeria Study to the subject's parents in their native language of Hausa, but did not fully translate the consent form. ${ }^{108}$ It has been alleged that the guardians would merely look at the administrators' faces and ask them to make a decision, indicating that they did not understand. ${ }^{109}$

Section 50.27 highlights regulations regarding documentation of informed consent. It states that "informed consent shall be documented by the use of a written consent form approved by the IRB and signed and dated by the subject or the subject's legally authorized representative at the time of consent. A copy shall be given to the person signing the form." ${ }^{110}$ The regulations also state that the consent form can either be written, or in a short form indicating that informed consent has been "presented orally to the subject or the subject's legally authorized representative ... [with a] witness to the oral presentation. Also, the IRB shall approve a written summary of what is to be said to the subject or the representative."111

Pfizer researchers allegedly failed to obtain proper written or oral consent in accordance with these regulations. While investigators constructed a consent form for the Study that was approved by a local committee, which was useless as most of the subjects and their guardians were illiterate. ${ }^{112}$ Pfizer could not produce any signed consent forms. ${ }^{113}$ Although Pfizer alleged that "verbal consent was obtained" and nurses talked to the families, ${ }^{114}$ Pfizer

${ }^{107} 21$ C.F.R. $\S 50.20$.

${ }^{108}$ Stephens, supra note 72.

${ }^{109} \mathrm{Id}$.

${ }^{110} 21$ C.F.R. $\S 50.27$ (a) (2011).

${ }^{111} 21$ C.F.R. $\S 50.27$ (b).

${ }^{112}$ Stephens, supra note 72.

${ }^{113}$ Id.

${ }^{114}$ Id. 
also admitted that no witnesses signed forms attesting that verbal consent was given. $^{115}$

\section{Allegations of Fraud}

Perhaps most striking was Pfizer's alleged engagement in fraud prior to, during, and following the research. ${ }^{116}$ As of this writing, publicly available knowledge on the Guatemala case has not implicated those researchers in fraud. In Nigeria, however, Pfizer allegedly falsely represented to the FDA, in seeking FDA approval for testing, that Pfizer had obtained proper approval of the local government and the IDH's ethics committee. ${ }^{117}$ Furthermore, a report later found that Pfizer allegedly never obtained approval from the Nigerian government to administer Trovan to the children and infants. ${ }^{118}$ The director of the National Agency for Food and Drug Administration and Control ("NAFDAC"), the Nigerian analog of the U.S. FDA, reportedly stated that his agency was not aware of the trial. ${ }^{119}$ Pfizer insists, however, that it "relied on approval letters and exemptions issued by NAFDAC, the Federal Ministry of Finance, [and] the Federal Ministry of Health."120

Pfizer is also alleged to have fraudulently identified its principal investigator. While Pfizer told Nigerian authorities that a Nigerian doctor was the principal investigator, an investigative committee reportedly later found that the doctor was only nominally the principal investigator, as American researchers directed the trial. ${ }^{121}$ In fact, the Nigerian principal investigator

\footnotetext{
${ }^{115}$ Shah, supra note 84.

116 "Fraud" and its derivatives are used within this article to mean "deceit, trickery, sharp practice, or breach of confidence, perpetrated for profit or to gain some unfair or dishonest advantage." See DICTIONARY.COM, available at http://dictionary .reference.com/browse/fraud.

${ }^{117}$ Wollensack, supra note 85.

${ }^{118}$ Stephens, supra note 75.

${ }^{119} \mathrm{Id}$.

${ }^{120}$ Statement of Defense, supra note 89.

${ }^{121}$ Stephens, supra note 75.
} 


\section{Volume 6 Issue 1}

Winter 2011

allegedly admitted that he was unaware of the experiment's results and did not see one publication of the results until after they were published. ${ }^{122}$

While the FDA regulations governing clinical research have provisions governing informed consent and protection of child subjects, there are no provisions explicitly protecting against fraud. In fact, as will be discussed below, much of what the FDA and others can do in the regulatory space does not and cannot address fraud. Therefore, the best solutions for human subject protection in this regard would be to increase oversight of the clinical trials where feasible, but more significantly, to provide a remedy in court for research subjects who have been harmed.

\section{Procedural history of the Pfizer Case}

The Washington Post broke the story of the Study in 2000, influencing the initiation of litigation. ${ }^{123}$ Families of the research subjects sued Pfizer in Nigeria and the United States, alleging that Pfizer had conducted the experiment without obtaining informed consent. ${ }^{124}$ The victims' families began U.S.-based litigation against Pfizer in a New York federal court in 2001, alleging Pfizer engaged in "cruel, inhuman and degrading treatment."125 Various U.S. courts issued decisions in September 2002, ${ }^{126}$ October 2003, ${ }^{127}$ August 2005, ${ }^{128}$ November $2005,{ }^{129}$ January $2009,{ }^{130}$ and November $2009 .{ }^{131}$

\footnotetext{
${ }^{122} I d$.

${ }^{123}$ George J. Annas, Globalized Clinical Trials and Informed Consent, 360 N. ENG. J. MED. 2050, 2051 (2009), available at http://content.nejm.org/cgi/reprint/360/20/ 2050.pdf.

${ }^{124} I d$. at 2051.

${ }^{125}$ Stephens, supra note 75.

${ }^{126}$ Abdullahi v. Pfizer, Inc., 2002 U.S. Dist. LEXIS 17436 (S.D.N.Y. Sept. 16, 2002).

${ }^{127}$ Abdullahi v. Pfizer, Inc., 77 F. App'x 48 (2d Cir. Oct. 8, 2003).

${ }^{128}$ Abdullahi v. Pfizer, Inc., 2005 U.S. Dist. LEXIS 16126 (S.D.N.Y. Aug. 9, 2005).

${ }^{129}$ Adamu v. Pfizer, Inc., 399 F. Supp. 2d 495 (S.D.N.Y. Nov. 8, 2005).

${ }^{130}$ Abdullahi v. Pfizer, Inc., 562 F.3d 163 (2d Cir. 2009).
}

$\mathrm{P}$ a g e $\mid \mathbf{2 0}$ 
Most recently, in June 2010, the U.S. Supreme Court rejected Pfizer's petition for a writ of certiorari. ${ }^{132}$

In July 2009, Pfizer reached a settlement with the Kano State government totaling \$75 million, in which the Kano State government dropped all criminal and civil charges against Pfizer. ${ }^{133}$ As part of the settlement, Pfizer denied all liability and wrongdoing associated with the Study. ${ }^{134}$ The settlement stipulated that Pfizer would 1) create a Healthcare/ Meningitis fund not to exceed $\$ 35$ million to provide financial support to those who can verify that they participated in the Nigeria Study; 2) fund $\$ 30$ million worth of future healthcare initiatives over two years chosen by the Kano State to benefit Kano State residents; and 3) pay Kano State \$10 million in legal fees. ${ }^{135}$ Two six-member boards will be set up by Pfizer and the Kano State to administer 1) the Healthcare/Meningitis Fund; and 2) the $\$ 30$ million health initiatives package. ${ }^{136}$ The settlement also stipulated that Pfizer would rebuild Kano's Infectious Disease Hospital ("IDH") ${ }^{137}$ and Pfizer began doing so in November 2010. ${ }^{138}$ Suits filed in Nigeria by the Nigerian government, and in New York by additional plaintiffs, ${ }^{139}$ were settled in February 2011. ${ }^{140}$ The specifics of this settlement were not disclosed. ${ }^{141}$

${ }^{131}$ Pfizer Inc. v. Abdullahi, 78 U.S.L.W. 3251 (Nov. 2, 2009).

${ }^{132}$ Pfizer Inc. v. Abdullahi, 130 S. Ct. 3541 (June 29, 2010).

${ }^{133}$ Pfizer, Kano State Reach Settlement of Trovan Cases, Business WiRE, July 20, 2009, available at http://mediaroom.pfizer.com/portal/site/pfizer/?ndmViewId=news view\& newsId=20090730005769\&newsLang=en.

${ }^{134}$ Id.

${ }^{135} I d$.

${ }^{136} \mathrm{Id}$.

${ }^{137}$ Editorial, Nigeria: Pfizer and Kano's Trovan Victims, DAILy CHAMPION (LAGOS), Feb. 12, 2010, available at http://allafrica.com/stories/201002120101.html.

${ }^{138}$ Kevin Grogan, Pfizer Builds New Nigeria Centre as Part of Trovan Deal, Pharmatimes OnLine, Nov. 25, 2010, available at http:/www.pharmatimes.com/ article/10-11-25/Pfizer_builds_new_Nigeria_centre_as_part_of_Trovan_deal.aspx.

${ }^{139}$ Joe Stephens, Pfizer to Pay \$75 Million to Settle Trovan-Testing Suit, WASH. Post, July 31, 2009, at A15, available at http://www.washingtonpost.com/wp-

P a g e | 21 
Volume 6 Issue 1

Winter 2011

However, some have questioned whether the settlement was fair to the families of the children who participated in the clinical research. While settling for $\$ 75$ million, the Nigerian and Kano State governments originally sought $\$ 9$ billion. ${ }^{142}$ A Connecticut attorney representing fifty-eight of the alleged victims recently commented that while in the final settlement Pfizer pays $\$ 10$ million each to the Nigerian government, the Kano State, and the Kano State's attorneys, it only pays $\$ 35$ million total to the 200 victims, meaning that each plaintiff gets only $\$ 175,000 .{ }^{143}$ Furthermore, the settlement does not provide an in-court remedy for those injured in human subjects research abroad. A cause of action under the Alien Tort Statute, discussed later in this article, could provide that remedy.

\section{TRANSPARENCY-FocuSEd REForms InSUFFICIENT to ProteCt HUMAN SUBJECTS}

Since the Nigeria Study, there have been several new and proposed modifications to clinical research protections, all of which have shortcomings. While providing some protections to subjects, these regimes will have little to no ability to prevent fraud and deficiencies in the informed consent process.

\section{A. International Clinical Trials Registry Platform ("ICTRP")}

The International Clinical Trials Registry Platform ("ICTRP") does not provide adequate protection to subjects abroad. Launched by the United

dyn/content/article/2009/07/30/AR2009073001847.html?nav=emailpage. See also Bill Berkrot, Pfizer Settles Remaining Nigerian and U.S. Trovan Suits, REUTERS, Feb. 22, 2011, available at http://www.reuters.com/article/2011/02/23/us-pfizeridUSTRE71M18U20110223.

${ }^{140}$ Berkrot, supra note 139.

${ }^{141} I d$.

${ }^{142}$ Stephens, supra note 139.

${ }^{143}$ Dave Collins, Lawyer Challenging Reported Pfizer Settlement, AssocIATED PRESS FINANCIAL WIRE, May 26, 2009, available at www.lexisnexis.com/lawschool. 
Nations through the World Health Organization ("WHO") in $2006,{ }^{144}$ the ICTRP's main focus was to persuade companies and institutions to register their clinical trials. ${ }^{145}$ Through the ICTRP, the WHO standardized what information companies should publicly register before commencing a trial. ${ }^{146}$ This information would ultimately constitute 20 key details, including information regarding funding and study design. ${ }^{147}$ By creating a standardized public registry, the hope of the WHO is to create a climate in which funding sources will make more informed and prudent decisions based on the ethics of the researchers. ${ }^{148}$

While creating a standardized public registry may theoretically have helped the Nigeria Study subjects by increasing transparency, the ICTRP fails to provide an adequate remedy to international clinical trials victims, such as those in the Nigeria Study, because the platform focuses on funding, identity of sponsors, and basic study design, not on the proper treatment of human subjects. ${ }^{149}$ Most importantly, the ICTRP does not address informed consent requirements or protect against violations, ${ }^{150}$ and it is only a voluntary guideline. $^{151}$

144 Molly McGregor, Uninformed Consent: The United Nations' Failure to Appropriately Police Clinical Trials in Developing Nations, 31 SuffolK TRANSNAT'L L. REV. 103, 109 (2007).

${ }^{145}$ Id. at $109-10$.

${ }^{146} I d$. at 111 .

${ }^{147}$ UN Health Agency Sets New Standards for Registration of All Human Medical Research, U.N. DAILY NEWS, May 19, 2006, available at http://www.un.org/ news/dh/pdf/english/2006/19052006.pdf [hereinafter UN Health Agency].

${ }^{148}$ McGregor, supra note 144, at 112 \& 124.

${ }^{149}$ Id. at 120. See also UN Health Agency, supra note 147.

${ }^{150}$ McGregor, supra note 144, at 116-17.

${ }^{151} I d$. at 117.

$\mathrm{P}$ a g e $\mid \mathbf{2 3}$ 
Volume 6 Issue 1

Winter 2011

\section{B. Registration of International Clinical Trials}

Another proposal that would similarly fall short in protecting subjects is the establishment of a public registry of international clinical trials. According to one expert, a public registry "standardized and validated by a reliable source would be invaluable in improving data, trials and patient safety." ${ }^{152}$ The Government Accountability Project ("GAP") suggests that this registry build upon the existing federal clinical registry. ${ }^{153}$ Registration would require sponsors to disclose both positive and negative information, which would reduce the likelihood of sponsors withholding unfavorable trial information. ${ }^{154}$ One proponent of this idea cites ClinicalTrials.gov as a potential model. ${ }^{155}$

Some have criticized the potential effectiveness of an international public registry. According to the GAP, the current public registry in place does not list all clinical trials being conducted worldwide. ${ }^{156}$ A drug company can still maintain unregistered trials, and fail to report unsatisfactory results with impunity. ${ }^{157}$ Giving the FDA subpoena power would assist the FDA in bringing unfavorable data to light. ${ }^{158}$ In addition, new legislation supplementing the FDA Amendment Act's provisions on clinical trial registration may increase the incidence of public disclosure. ${ }^{159}$

${ }^{152}$ Barry Malkin, Expert: International Trials Face Ethical, Monitoring Challenges, CliniCAL TRIALS AdVISOR, Jan. 22, 2009, available at www.lexisnexis.com/ lawschool.

${ }^{153}$ GAP Calls on Congress, FDA to Impose More Clinical Trial Oversight, FDA WEEK, Apr. 17, 2009, available at www.lexisnexis.com/lawschool [hereinafter GAP Calls on Congress].

${ }^{154}$ Malkin, supra note 152.

${ }^{155} \mathrm{Id}$.

${ }^{156}$ GAP Calls on Congress, supra note 153.

${ }^{157} I d$.

${ }^{158} I d$.

${ }^{159}$ Malkin, supra note 152. 
The ICTRP, discussed above, may serve as a model or foundation for such a public registry. However, the ICTRP's focus on the need to increase public availability of clinical research data is insufficient to solve the problems discussed earlier in this article. The ITCRP's proponents seem to believe, perhaps mistakenly, that the public will serve as adequate watchdogs and be able to quickly respond to ethical violations in the midst of epidemics, given the pressing need for drugs. ${ }^{160}$ Lastly, because the major flaws of the Trovan experiment included alleged fraud and deficiencies in informed consent, and that hundreds of registries existed at that time, it is unlikely that the ICTRP or a similar registry could have guarded against Pfizer's misconduct. ${ }^{161}$

\section{NEW AND PROPOSED IMPROVEMENTS IN THE REGULATORY REGIME}

The FDA recently passed new regulations that offer promise for greater protection of human subjects abroad. These regulations include a good clinical practice ("GCP") standard, independent ethics committee ("IEC") requirements, more informed consent regulations, as well as greater documentation and reporting of the study design.

According to several senior FDA officials, the FDA hopes to issue more binding regulations, rather than persuasive guidance in the clinical trials space. ${ }^{162}$ This is evidenced by the FDA's April 2008 promulgation of a final rule regarding "foreign clinical studies not conducted under an investigational new drug application." ${ }^{163}$ The new regulations went into effect on October 27, $2008 .^{164}$

\footnotetext{
${ }^{160}$ McGregor, supra note 144, at 103, $122 \& 124-25$.

${ }^{161} I d$. at 120.

${ }^{162}$ FDA Official Sees Push for Clinical Trial Rules Rather Than Guidance, DRUG INDUSTRY DAILY, Apr. 29, 2008, available at www.lexisnexis.com/lawschool.

16373 Fed. Reg. 22,800 (Apr. 28, 2008).

${ }^{164}$ Douglas Peddicord, Clinical Trials Adhere to the Highest Standards, STRAITS TIMES (SINGAPORE), June 13, 2009, available at www.lexisnexis.com/lawschool. Also see 73 Fed. Reg. at 22,800 .
}

$\mathrm{P}$ a g e $\mid \mathbf{2 5}$ 


\section{Volume 6 Issue 1}

Winter 2011

\section{A. Good Clinical Practice ("GCP")}

While the FDA previously had authority over foreign clinical studies by the ethical guidelines set forth in the Declaration of Helsinki, the 2008 rule now holds these trials to the standards of Good Clinical Practice ("GCP"). ${ }^{165}$ The final rule defines GCP "as a standard for the design, conduct, performance, monitoring, auditing, recording, analysis, and reporting of clinical trials in a way that provides assurance that the data and reported results are credible and accurate and that the rights, safety, and well-being of trial subjects are protected." 166 The FDA further defines GCP as including pre-study review and approval by an IEC, ongoing review by the IEC during the study, and "obtaining and documenting" informed consent of the subject or her legally authorized representative prior to a study. ${ }^{167}$ Further elements of GCP include 1) providing supporting documentation; and 2) if necessary, submitting to an onsite inspection. ${ }^{168}$

\section{B. REVIEW BY INDEPENDENT ETHICS COMMITTEe ("IEC")}

The new FDA rule mandates that such trials be reviewed and approved by an Independent Ethics Committee ("IEC"). ${ }^{169}$ The rule defines an IEC "as a review panel that is responsible for ensuring the protection of the rights, safety, and well-being of human subjects involved in a clinical investigation and is adequately constituted to provide assurance of that protection." ${ }^{170}$ The final rule also clarifies that an IRB is a form of IEC. ${ }^{171}$

According to the final rule, the applicant or sponsor must submit information including the name and address of the IEC, a statement that the

\footnotetext{
16573 Fed. Reg. at 22,800.

${ }^{166} I d$. at 22,806 .

${ }^{167}$ Id. at 22,801 .

${ }^{168} I d$. at 22,806 .

${ }^{169}$ Id. at 22,800 .

${ }^{170} I d$. at 22,801 .

${ }^{171} I d$. at 22,805 .
} 
IEC qualifies under $\S 312.3$, supporting documentation to verify the identities and qualifications of IEC members, and a summary of the IEC's approval, modification, or favorable opinion of the study. ${ }^{172}$ The applicant, or sponsor, is also required to maintain records supporting the statement of qualification as an IEC, in addition to the identities of the qualifications of IEC members, in the event of an agency review. ${ }^{173}$

An IEC requirement provides inadequate protection for international human subjects. As discussed above, the Trovan trials were conducted without an IRB. Thus, the problem with the trial was not that there was not an IRB, but that reportedly, Pfizer fraudulently led the FDA to believe that there was one. ${ }^{174}$ The rule's provisions regarding IECs do not provide a safeguard against fraudulent conduct.

This regulation lacks teeth given the shortage of FDA staff and small number of inspections worldwide. This regulation is also ambiguous. The IEC must review and approve a clinical study before implementation, but the rule does not specify the exact procedures required by the IEC. ${ }^{175}$ The FDA is aware of and defends this ambiguity: it states that it did not articulate such specifics "because different procedures offering equivalent human subject protection may be followed in different countries." ${ }^{176}$ The rule stated that the GCP standards in general, and the mandate of the IEC to review and approve specifically, "are and should be sufficiently flexible to accommodate differences in how countries regulate the conduct of clinical research, while ensuring adequate and comparable human subject protection." ${ }^{177}$ While different countries undoubtedly demonstrate acceptable differences in how they regulate clinical trials, the ambiguity of this standard may lead to abuse. For example, accepting a multi-layered informed consent approach involving

\footnotetext{
${ }^{172} I d$. at $22,801-02$.

${ }^{173} I d$.

${ }^{174}$ Wollensack, supra note 85 , at 756 .

17573 Fed. Reg. at 22,807.

${ }^{176}$ Id.

${ }^{177} I d$.
} 
Volume 6 Issue 1

Winter 2011

different members of the community, while in one instance producing viable and culturally sensitive informed consent, would be prone to corruption in a different situation. The FDA should clarify what constitutes appropriate, informed consent to provide sponsors and researchers with clear boundaries. This might be accomplished by providing non-exhaustive lists of both acceptable and unacceptable ways in which informed consent practices can and cannot be changed to take into account cultural norms and understandings. These non-exhaustive lists would in turn give the FDA greater discretion as reasonably necessary.

\section{INFORMED CONSENT REQUIREMENTS}

The new final rule provides additional protections regarding informed consent. It mandates that the sponsor/applicant disclose to the FDA descriptions of how informed consent was obtained from the subjects. ${ }^{178}$ This may increase transparency and encourage sponsors to properly obtain informed consent. Increased disclosure may also help ensure that the sponsor adequately conveys information regarding alternative treatments and the fact that the subjects are involved in a clinical study and not proven therapy.

The final rule also sets a high bar for when sponsors are exempt from obtaining informed consent. The rule does not require informed consent under certain limited, life-threatening situations. ${ }^{179}$ In such a situation, the IEC must conduct its review prior to the study's commencement. ${ }^{180}$ The IEC must also find that obtaining informed consent is not feasible. ${ }^{181}$ Finally, the IEC must find either that 1) the life-threatening situation is "consistent" with those articulated in 21 C.F.R. $\S 50.23$ or 21 C.F.R. $\S 50.24$ (a), or 2 ) "that the measures described in the study protocol or elsewhere will protect the rights, safety, and well-being of subjects." ${ }^{182}$

\footnotetext{
${ }^{178} I d$. at $22,801-22$.

${ }^{179} I d$. at 22,801 .

${ }^{180} I d$. at 22,806 .

${ }^{181} I d$. at 22,816 .

${ }^{182}$ Id. at 22,816 .
} 


\section{SUPPORTING INFORMATION REQUIREMENTS}

Under the new rule, the sponsor or applicant must submit "the investigator's qualifications." ${ }^{183}$ This may serve as a safeguard against fraudulently representing the principal investigator, as occurred in the Nigeria Study. Perhaps more importantly, the new rule adds additional regulation to promote sound protocol and study set-up and execution, including a comprehensive protocol summary, study results, and case records and additional background data regarding study integrity upon request. ${ }^{184}$ Furthermore, the sponsor must submit documentation of how it monitored the study, and how the sponsor maintained consistency with the protocol. ${ }^{185}$ The authority of the FDA to request "case records or additional background data" may also limit abuse, as it will allow the FDA to see individual case histories. ${ }^{186}$

\section{E. Potential Onsite Inspection}

The FDA's onsite inspection power in this final rule is particularly encouraging. However, it is questionable how viable onsite inspections are, given their cost and the lack of political support they will likely receive. International monitoring is currently not a priority of the FDA, as it does not even inspect 3,500, or one percent, of its 350,000 registered trial sites. ${ }^{187}$ One commentator suggested that the FDA "be provided sufficient resources to conduct inspections on a global basis" to ensure greater human subjects protection abroad. ${ }^{188}$ However, it is unlikely that the government can realize this vision given funding concerns. Despite the Office of the Inspector General ("OIG") of the Department of Health and Human Services ("HHS")

\footnotetext{
${ }^{183} I d$. at 22,802 .

${ }^{184} \mathrm{Id}$.

${ }^{185} I d$. at 22,802 .

${ }^{186} \mathrm{Id}$.

${ }^{187}$ Shetty, supra note 1.
}

${ }^{188}$ Clinical Research Safety and Ethical Standards in Developing World Up to U.S. Levels, Report Says, PR NewSWIRE, July 21, 2009, available at http://www.lexisnexis .com/lawschool. 
Volume 6 Issue 1

Winter 2011

recommending in a recent report that the FDA "inspect clinical trials in more countries," ${ }^{189}$ the OIG admits in that very same report, "[w]ith inspections costing about $\$ 40,000$ each and the additional logistical challenges of conducting inspections at foreign sites, it may be more difficult for [the] FDA to justify a foreign inspection." ${ }^{190}$

Perhaps a viable alternative may be to shift the cost burden of onsite inspections to the host countries. One proponent of this approach has argued for host countries to strengthen their own regulatory agencies' monitoring of investigators and research, and to share that information with the FDA "so it doesn't fall on the FDA to be the police for global clinical research." ${ }^{191}$ The OIG of HHS recently echoed this proposal, calling for the FDA to "continue to develop inspectional agreements with foreign regulatory bodies." ${ }^{192}$ In addition, Congress could grant authority to the FDA to require that pharmaceutical companies fund their onsite inspections in part or entirely, perhaps in an act similar to the existing domestic Prescription Drug User Fee Act ("PDUFA"). ${ }^{193}$ However, opponents of private funding for inspections of foreign drug manufacturing plants point out that doing so "will make the agency beholden to manufacturers and more apt to overlook production flaws." ${ }^{194}$ A similar risk is possible in private funding of foreign study inspections, as the FDA may be less willing to be objectively critical during inspections given its source of funding.

${ }^{189}$ Daniel R. Levinson, Challenges to FDA's Ability to Monitor and Inspect Foreign Clinical Trials, OfFice of THE InSPECTOR GENERAL AT THE DEPARTMENT OF HEALTH AND HUMAN SERVICES, June 2010, at 21, available at http://oig.hhs.gov/oei/reports/ oei-01-08-00510.pdf.

${ }^{190} \mathrm{Id}$.

${ }^{191}$ O'Reilly, supra note 4.

${ }^{192}$ Levinson, supra note 189.

${ }^{193}$ See Prescription Drug User Fee Act, FOOD \& DRUG ADMIN., available at http:/www.fda.gov/ForIndustry/UserFees/PrescriptionDrugUserFee/default.htm.

${ }^{194}$ Drew Armstrong, For FDA, Congress Readies a Bitter Pill, CQ WEEKLY, Apr. 7, 2008, at 868, available at http://public.cq.com/docs/cqw/weeklyreport110-0000026 97959.html.

P a g e | 30 


\section{F. Applying the Maryland Model to Federal LaW Could Further enhance Protection}

Congress could protect all human subjects of American pharmaceutical companies abroad by enacting federal legislation similar to the legislation passed in Maryland. Congress has yet to enact overarching regulation on all domestic human subjects research, which it has already done with animal research. ${ }^{195}$ Human research subjects abroad are similarly not universally protected by federal regulations. They are protected only if the research is at least partially funded by the 17 federal agencies "that have adopted the Common Rule." ${ }^{196}$ The FDA then provides additional protection for subjects involved in research obtained as part of an application for approval to market a drug, device, or biologic product. ${ }^{197}$

The Maryland law, which became effective on October 1, 2002, mandates that all clinical research in Maryland comply with HHS and FDA regulations, regardless of whether or not the research receives federal funds. ${ }^{198}$ The GAP has recommended that Congress extend protection to all human subjects in the United States, possibly by using Maryland's law as a template. ${ }^{199}$ Congress could take GAP's suggestion one step further by subjecting all clinical trials abroad sponsored by American pharmaceutical companies to HHS and FDA regulations, regardless of whether the trials receive funds from these agencies.

Congress could incorporate other aspects of the Maryland law to further protect human subjects abroad. Most importantly, the Maryland model enables enforcement by authorizing Maryland's Attorney General "to seek

${ }^{195}$ GAP Calls on Congress, supra note 153.

${ }^{196} \mathrm{Id}$.

${ }^{197} I d$.

${ }^{198}$ Wallace Witkowski, Maryland IRB Law Has No Money for Enforcement, But 'Important Step' In Accountability, Attorney Says, BIORESEARCH MonITORING ALERT, Aug. 1, 2002, available at http://www.accessmylibrary.com/article-1G1-93955971/ maryland-irb-law-has.html.

${ }^{199}$ GAP Calls on Congress, supra note 153. 


\section{Volume 6 Issue 1}

Winter 2011

injunctive or other relief" if research is non-compliant with federal regulations. ${ }^{200}$ If Congress chose to adopt the Maryland rule as suggested above, an analogous federal enforcement mechanism would similarly promote the efficacy of the regulations.

While promising at first glance, there are significant obstacles to Congressional adoption of the Maryland model. There may be constitutional limitations on the scope of the model, as scholars have commented that scientific research is protected under the Free Speech Clause of the First Amendment. ${ }^{201}$ Furthermore, applying the Maryland law to the Nigeria Study would have been superfluous given that the Study, as established above, was already subject to FDA regulations. ${ }^{202}$ There would also likely be a lack of political will in overseeing international drug testing not being funded by FDA or HHS. The fact that these trials are not receiving FDA or HHS funding would beg the question as to who would oversee these trials, and what that agency's interest would be in doing so. Federal agencies would likely be disinclined to oversee clinical trials where they had no financial stake. One option is for the federal government to collect fines for noncompliance, but fines would have to be significant enough to justify the costs associated with oversight.

\section{Nigeria STUDY LITIGATION OPENS DOOR FOR ALIEN TORT STATUTE REMEDY}

The most recent litigation in Abdullahi v. Pfizer opened the door for use of the Alien Tort Statute ("ATS") ${ }^{203}$ as a cause of action used by human

\footnotetext{
${ }^{200}$ Adil E. Shamoo \& Jack Schwartz, Universal and Uniform Protections of Human Subjects in Research, 8 AM. J. BIOETHICS 3, 4 (2008).

${ }^{201}$ Steve Keane, The Case Against Blanket First Amendment Protection of Scientific Research: Articulating a More Limited Scope of Protection, 59 STAN. L. REV. 505, 506 n.5 (2006).

202 The Maryland Model would have been inapplicable to the Guatemala study, because at the time of the study there were no regulations with which to comply.

${ }^{203}$ The ATS is codified in 28 U.S.C. $\S 1350$ and consists of one sentence: "The district courts shall have original jurisdiction of any civil action by an alien for a tort only, committed in violation of the law of nations or a treaty of the United States."
}

P a g e $\mid 32$ 
subjects against American pharmaceutical companies for conduct abroad. In January 2009, The United States Court of Appeals, Second Circuit, reversed and remanded an earlier 2005 Abdullahi v. Pfizer District Court opinion, holding "that the district court incorrectly determined that the prohibition in customary international law against nonconsensual human medical experimentation cannot be enforced through the ATS." ${ }^{204}$

The Court of Appeals argued for a more nuanced understanding of the application of international standards to U.S. courts vis-à-vis the ATS. Applying Sosa v. Alvarez-Machain, ${ }^{205}$ the Court of Appeals noted that a federal court can recognize a violation of international law and a cause of action under the ATS "only if a plaintiff identifies the violation of a norm of customary international law that, as defined by the sources of such law ... is sufficiently specific, universal, and obligatory." ${ }^{206}$ The Court of Appeals found the District Court's application of Sosa's "sufficiently specific, universal, and obligatory" test erroneous, as the District Court only looked at whether each international law referencing the norm is binding and has an express cause of action. ${ }^{207}$ The Court of Appeals argued that, under Sosa, "[c]ourts are obligated to examine how the specificity of the norm compares with 18th-century paradigms, whether the norm is accepted by the world community, and whether States universally abide by the norm out of a sense of mutual concern." 208 Consequently, the Court of Appeals held that the District Court incorrectly determined that international law cannot be

Presbyterian Church of Sudan v. Talisman Energy, Inc., 244 F. Supp. 2d 289, 303 (S.D.N.Y. Mar. 19, 2003). Congress codified it into law as part of the Judiciary Act of 1789 , but it was "only invoked a handful of times for nearly two hundred years." Id. at 304. The 1980 case Filartiga v. Pena-Irala brought the ATS out of obscurity, when the Second Circuit held that the ATS allowed federal courts to adjudicate "rights already recognized by international law." Id. at 304, citing Filartiga v. Pena-Irala, 630 F.2d 876, 887 (2d Cir. 1980).

${ }^{204}$ Abdullahi v. Pfizer, Inc., 562 F.3d 163, 177 (2d Cir. 2009).

${ }^{205}$ Sosa v. Alvarez-Machain, 542 U.S. 692, 720, 723, 725, 728-29 (2004).

${ }^{206}$ Abdullahi v. Pfizer, Inc., 562 F.3d at 174.

${ }^{207}$ Id. at 176.

${ }^{208} I d$. 


\section{Volume 6 Issue 1}

Winter 2011

enforced through the ATS to prohibit nonconsensual human subject research, and reversed and remanded the lower court's ruling. ${ }^{209}$

The 2009 decision suggests that redress in American courts for human subjects abroad is possible under the ATS because human subjects protections are universally accepted in international law. Several other U.S. courts have also taken this position. ${ }^{210}$

The 2009 Abdullahi v. Pfizer opinion stated that the Nuremberg trials established the prohibition of nonconsensual medical experimentation on human subjects as a "norm of customary international law" which is recognized by "states throughout the world ... through international accords and domestic law-making." ${ }^{111}$ The Code states that "the voluntary consent of the human subject is absolutely essential" and that "the duty and responsibility for ascertaining the quality of the consent rests upon each individual who initiates, directs, or engages in the experiment." ${ }^{212}$ Furthermore, the court held that the Nuremburg trials' "authorizing documents" and judgments established legal principles that became the "bedrock norms of international law."213

${ }^{209}$ Id. at 169.

${ }^{210}$ See, e.g., Grimes v. Kennedy Krieger Inst., Inc. 782 A.2d 807, 835-36, 849-50 (Md. 2001). The permissibility of using the Nuremberg Code in U.S. courts was also addressed in a dissent involving a case of U.S. government sponsored human experimentation. See, e.g., United States v. Stanley, 483 U.S. 669, 687, 710 (1987).

${ }^{211}$ Abdullahi v. Pfizer, Inc., 562 F.3d at 177-79.

${ }^{212}$ The United National International Covenant on Civil and Political Rights, Article 7, The Human Rights WeB PAGE, available at http://www.hrweb.org/legal/cpr.html.

${ }^{213}$ The Declaration of Helsinki's, and the Nuremberg Code's long established history of influencing government regulation further suggested to the court that it carried substantive weight in laying the foundation of American human subjects regulation: "Congress mandated patient-subject consent in drug research in $1962 \ldots$. in response, the FDA promulgated its first regulations requiring the informed consent of human subjects. Tellingly, the sources on which our government relied in outlawing nonconsensual human medical experimentation were the Nuremberg Code and the Declaration of Helsinki, which suggests the government conceived of these sources' articulation of the norm as a binding legal obligation." See id. at 179.

P a g e $\mid \mathbf{3 4}$ 
The Court also held that the Declaration of Helsinki, adopted by the World Medical Association in 1964 and most recently amended in 2008, constituted a norm of customary international law. ${ }^{214}$ The Declaration of Helsinki created twenty "principles of all medical research," including those involving informed consent and appropriate risk of human subjects research. ${ }^{215}$ The court found that the United States and at least eighty-three other countries have incorporated the Declaration of Helsinki into their laws regulating informed consent of human subjects, ${ }^{216}$ which the Court found "a powerful indication of the international acceptance of this norm as a binding legal obligation." 217

Article 7 of the United Nations' International Covenant on Civil and Political Rights ("ICCPR") was also recognized by the Court as a customary norm of international law. Article 7 of the ICCPR states, "[N]o one shall be subjected without his free consent to medical or scientific experimentation." ${ }^{218}$ The court recognized that this provision "is legally binding on the more than 160 [s]tates-[p]arties that have ratified the convention without reservation to the provision," ${ }^{219}$ and offers protection to human subjects against "state actors, private actors, or state and private actors behaving in concert." 220 The court concluded, "[t]he international community's recognition in the ICCPR of its obligation to protect humans against nonconsensual medical experimentation, regardless of the source of the

\footnotetext{
${ }^{214} I d$. at 182.

${ }^{215}$ WMA Declaration of Helsinki-Ethical Principles for Medical Research Involving Human Subjects, WORLD MEDICAL ASSOC., available at http://www.wma.net/en/ 30publications/10policies/b3/.

${ }^{216}$ See Abdullahi, 562 F.3d at 179.

${ }^{217}$ Id. at 179.

${ }^{218}$ Supra note 212.

${ }^{219}$ See Abdullahi, 562 F.3d at 180.

${ }^{220}$ Id. at 180.
} 


\section{Volume 6 Issue 1}

Winter 2011

action, is powerful evidence of the prohibition's place in customary international law." 221

Nonetheless, while the Second Circuit Court of Appeals argued in the 2009 Abdullahi v. Pfizer case that a corporate defendant may be tried under the ATS, the Second Circuit split on this issue in 2010 when a separate panel determined that the ATS can be used to seek redress against an individual but not a corporate defendant. ${ }^{222}$ Until this circuit split is resolved, it remains an open question whether or not an ATS claim can definitively be brought against a corporate defendant, but one that trial sponsors should be aware of.

\section{NeW Guatemala Study Class ACtion Complaint InCREASES PROMISE OF ATS REMEDY}

A class action complaint, filed on March 14, 2011 by the victims and surviving family members of the Guatemala Study, also seeks remedy under the ATS. ${ }^{223}$ This time, however, the ATS would provide human subjects with a cause of action against the American government, as the Guatemala Study was a federally funded trial conducted abroad. ${ }^{224}$ The complaint, filed in the United States District Court for the District of Columbia, involved seven plaintiffs, with the number of potential class members estimated in the "thousands." 225 The ATS served prominently in the complaint. One of the two questions of law and fact was "[w]hether Plaintiffs and [p]roposed [c]lass $[\mathrm{m}]$ embers were unlawfully subjected to non-consensual human medical experimentation in violation of 'the law of nations' provision of the Alien Tort Statute." ${ }^{226}$ The complaint later alleged that the Plaintiffs' cause of action

${ }^{221} I d$.

${ }^{222}$ Sue Reisinger, WikiLeaks Sparks Interest in Pfizer Court Battle-as 2nd Circuit Splits on Alien Tort Statute, CORPORATE COUNSEL, available at http://www.law.com/ jsp/cc/PubArticleCC.jsp?id=1202479602161.

${ }^{223}$ Garcia v. Sebeliua, Complaint, case no. 1: 11-cv-00527, filed on Mar. 14, 2011, in District Court for District of Colombia at 31.

${ }^{224} \mathrm{Id}$. at 12.

${ }^{225}$ Id. at 7, 9.

${ }^{226}$ Id. at 9. 
arises from the ATS, the ICCPR, and the Nuremberg Code, among other "laws, agreements, conventions, resolutions and treaties." 227 The plaintiffs rested both their first claim for relief, the "violation of prohibition against medical experimentation on non-consenting human subjects," as well as their second claim for relief, the "violation of prohibition against cruel, inhuman, or degrading treatment," on the ATS. ${ }^{228}$ The first claim of relief incorporated the ICCPR and the World Medical Association's Declaration of Helsinki, while the second claim of relief cited the ICCPR as well. ${ }^{229}$

\section{LEGISLATIVE AND JUDICIAL APPROACHES TO INTERNATIONAL STANDARDS AND THE ATS}

As demonstrated by the recent developments mentioned above in the Nigeria and Guatemala cases, multiple plaintiffs are now seeking to use the ATS as a remedy for violations of internationally accepted protections/rights. In light of high profile cases like Nigeria and Guatemala, there may be a groundswell of support for a remedy through the ATS, which could lead Congress to take action. The United States Congress could guarantee a remedy for injured human subjects abroad if, through legislation, it clarifies the relationship between international law and the Alien Tort Statute. ${ }^{230}$ Specifically, the legislature could either 1) adopt specific international laws as binding, or 2) merely recognize currently non-binding international law as norms for the purpose of creating a cause of action under the Alien Tort Statute. $^{231}$

One solution is for Congress to adopt the ICCPR as binding law, and through the ICCPR create a right of action under the ATS. ${ }^{232}$ Alternatively, the legislature could simply recognize the ICCPR's guidelines as norms,

\footnotetext{
${ }^{227} I d$. at 23 .

${ }^{228} I d$. at $24,26$.

${ }^{229}$ Id. at $25,27$.

${ }^{230}$ Wollensack, supra note 85 , at 770 .

${ }^{231} \mathrm{Id}$.

${ }^{232} I d$.
} 
Volume 6 Issue 1

Winter 2011

creating an action under the ATS. Similarly, the United States could give plaintiffs a right of action against U.S. pharmaceutical companies by acknowledging the current "voluntary ethical guidelines [of the Nuremberg Code] as norms." 233 Binding American pharmaceutical companies to Nuremberg would be one way to hold them accountable for their protocols. ${ }^{234}$

The Nuremberg Code is an alternative that appears to be the favorite vehicle for establishing a remedy under the ATS. Several U.S. courts have addressed the relevance of the Nuremberg Code to ATS cases relating to human subject research. ${ }^{235}$ In Grimes v. Kennedy Krieger Inst., Inc., the court stated, "the Nuremberg Code ... was the result of legal thought and legal principles, as opposed to medical or scientific principles, and thus should be the preferred standard for assessing the legality of scientific research on human subjects." ${ }^{236}$ However, the Nuremberg Code's universal restriction on child research may make it an unviable candidate for establishing a cause of action given countervailing U.S. policies, such as National Institutes of Health guidelines that require inclusion of children in all human subjects research, unless exclusion can be justified. ${ }^{237}$ After all, data from adult trials is often unhelpful in developing treatments for childhood diseases, in which pathophysiology and toxicities may be different. For human subjects research involving children, Congress or the Courts could opt to create a right of

\footnotetext{
${ }^{233} I d$.

${ }^{234}$ Yevgnia Shtilman, Pharmaceutical Drug Testing in the Former Soviet Union: Contract Research Organizations as Broker-Dealers in an Emerging Testing Ground for America's Big Pharma, 29 B.C. THIRD WORLD L.J. 425, 454 (2009).

${ }^{235}$ Wollensack, supra note 85 , at 770 .

${ }^{236} I d$.

${ }^{237}$ The United National International Covenant on Civil and Political Rights, Article 7, The Human Rights WeB PAGE, available at http://www.hrweb.org/legal/cpr.html. The Nuremberg Code excludes children from human subjects research in its first article, stating: "The voluntary consent of the human subject is absolutely essential. This means that the person involved should have legal capacity to give consent ...." NIH Policy and Guidelines on the Inclusion of Children as Participants in Research Involving Human Subjects, Mar. 6, 1998, available at http:/grants.nih.gov/grants/ guide/notice-files/not98-024.html.
} 
action using the ATS, either through the Declaration of Helsinki or the ICCPR.

Once either Congress or the courts recognize a right of action under the ATS, Congress could then set up a voluntary plaintiffs' forum. Some contend that this forum should be set up in the United States, ${ }^{238}$ while others argue for a forum in "any country where a pharmaceutical company conducts its clinical research" in order to avoid unnecessary hardship of plaintiffs needing to travel to the United States. ${ }^{239}$ Establishing a forum in another country, however, could result in unintended negative consequences, such as dramatically increasing the number of lawsuits against American companies, resulting in increased litigation costs, and likely leading to higher numbers of confidential settlements. This option would do little to increase transparency, and could result in delays in the development of life saving drugs as well as increased costs for such drugs.

\section{CONCLUSION}

Clinical studies in the developing world are commonly marred by 1) deficiencies in the informed consent process; 2) flaws in research design and/or execution; and 3) allegations of fraud. ${ }^{240}$ As both the Guatemala and Nigeria Studies demonstrate, international human subjects, particularly those in developing nations, are vulnerable to harms emanating from these deficiencies, and currently do not have an adequate avenue for redress. ATS litigation represents a beacon of hope for harmed foreign research subjects, who, thanks to the January 2009 Abdullahi v. Pfizer decision and the U.S. Supreme Court's subsequent rejection of Pfizer's petition for a writ of certiorari, have the option of bringing cases in U.S. courts. The recent Garcia $v$. Sebelius class action has breathed new life into the viability of an ATS complaint based on breaches of international law norms, this time against a

\footnotetext{
${ }^{238}$ Wollensack, supra note 85 , at 769.

${ }^{239}$ Shtilman, supra note 234, at 453.

${ }^{240}$ Kohar Jones, Editorial, A Flawed Approach to Drug Testing, Wash. Post, May 18, 2006, at A22, available at http://www.washingtonpost.com/wp-dyn/content/ article/2006/05/17/AR2006051701902.html.
} 
Volume 6 Issue 1

Winter 2011

state actor. Furthermore, a recent FDA final rule will provide human subjects with additional protections by strengthening the IEC and informed consent regimes and establishing a vehicle for onsite inspections. A new cause of action under the ATS, and a more robust regulatory regime that ensures informed consent, proper study design and execution, and FDA oversight appears to be on the horizon. 